- Presents the range and relative frequency of histological specimens submitted by GDPs.

- Few GDPs regularly submit specimens despite the importance of histopathological confirmation of a clinical diagnosis.

- Small incisional and excisional biopsies are within the scopes of specialist practitioners and GDPs.

- The quality of specimens submitted by GDPs is similar to that of their hospital colleagues.

\title{
A survey of oral and maxillofacial pathology specimens submitted by general dental practitioners over a 30-year period
}

\author{
C. D. Franklin ${ }^{1}$ and A. V. Jones ${ }^{2}$
}

\begin{abstract}
Objectives To determine the range and frequency of diagnoses in specimens submitted for histopathological examination by general dental practitioners (GDPs).

Methods A retrospective analysis was carried out of all cases submitted by GDPs for the period 1974-2003, using a Foxpro ${ }^{\mathrm{TM}}$ Windows database. The data were collated into 10 diagnostic categories each comprising number of diagnoses, percentage of each diagnosis within a diagnostic category and each diagnosis as a percentage of total cases.

Results GDPs submitted 6,666 cases out of a total of 53,474 for this period. While the total number of specimens increased four-fold over the 30 -year period, specimens from GDPs increased from 7\% to 17\%. The range of diagnoses increased from 18 to 45 . Of the 617 GDPs who submitted material, 279 (45\%) submitted less than two specimens each in 30 years. Nine malignant neoplasms were diagnosed. Other significant pathology included 320 benign neoplasms as well as diagnoses ranging from mucosal lesions such as lichen planus to odontogenic cysts.

Conclusions It is clear that GDPs have provided an increased number of biopsy specimens over the last three decades. This reflects an increasing demand by GDPs for a diagnostic oral histopathology service and their use of this service should be encouraged.
\end{abstract}

\section{INTRODUCTION}

General dental practitioners have largely been discouraged, by oral and maxillofacial surgeons, from taking surgical biopsy specimens. ${ }^{1}$ In the last decade or so, undergraduate training in dental specialty areas such as oral and maxillofacial surgery, oral medicine and oral pathology, ${ }^{2}$ has changed to increase confidence in diagnostic as well as surgical skills. Thomas et al. ${ }^{3}$ reported that the number of tooth based surgical procedures performed within the general dental service increased significantly between 1984 and 1991. With the advent of specialist practice in surgical

\footnotetext{
${ }_{1 *}$ Postgraduate Dean and Honorary Consultant in Oral and Maxillofacial Pathology, Department of Oral Pathology, School of Clinical Dentistry, University of Sheffield, Claremont Crescent, Sheffield, S10 2TA; ${ }^{2}$ Specialist Registrar in Oral and Maxillofacial Pathology, Department of Oral Pathology, School of Clinical Dentistry, Claremont Crescent, Sheffield, S10 2TA

${ }^{*}$ Correspondence to: Dr Christopher Franklin

Email:c.franklin@sheffield.ac.uk
}

\section{Refereed paper}

Accepted 15 June 2005

doi: 10.1038/sj.bdj.4813464

() British Dental Journal 2006; 200: 447-450 dentistry, the development of practitioners with special interests, as well as improved undergraduate training, this trend may well increase; hence the number of biopsies submitted for histological diagnosis from general dental practitioners may also increase.

For some years, the Department of Oral Pathology in the School of Clinical Dentistry, Sheffield has recorded all acceded specimens into a diagnostic index using a Foxpro ${ }^{\mathrm{TM}}$ database. Part of the demographic information recorded is that of the clinician submitting a specimen. It is, therefore, possible to identify all those specimens submitted by general dental practitioners (GDPs). The department receives specimens from GDPs in the Sheffield area, from further afield in South Yorkshire and East Midlands (SY/EM) and from some practitioners (usually former Sheffield graduates or staff) outside these areas. Despite the number of practitioners in the Sheffield area (approximately 220) and the wider SY/EM region (approximately 1,800 ), the majority of general dental practitioner specimens come from about 300 who regularly submit material. There has been only one previous study of the use made by UK GDPs of a histopathology diagnostic service. ${ }^{4}$ The only other comparable reports are two studies within the USA. ${ }^{5,6}$ Levy $^{5}$ studied specimens submitted over a single year and found that 23\% of cases were from dental practitioners. In a further study, Weir ${ }^{6}$ reported on almost 16,000 biopsy specimens submitted to their department over a 17.5 year period. The source of their material was private practitioners (80\%) while the Faculty Dental Practice and student clinics made up the remainder. Other studies on biopsy samples submitted by GDPs were based on artefacts seen in biopsies submitted by GDPs ${ }^{7}$ and the attitudes of GDPs, oral surgeons and patients on biopsies performed in general practice. ${ }^{1}$ The purpose of this study was to carry out a survey of all specimens submitted to a diagnostic pathology service by GDPs over a 30-year period (1974-2003) in order to determine the diagnostic range and relevance of such material.

\section{METHOD}

Since 1989, data from all specimens received in the department have been prospectively entered into a computer database. Subsequently data from the files between 1973 and 1988 were computerised. The structure of the database has been modified several times and a Foxpro ${ }^{\mathrm{TM}}$ Windows database is now used. Initial demographic data is entered by technical staff, when the specimen is received, and the record completed by secretarial staff when the final report has been issued. The diagnoses are entered 


\begin{tabular}{lll}
\multicolumn{4}{l}{ Table 1 Oral pathology specimens received from GDPs (1974-2003) } \\
\hline Diagnostic category & Total cases & \% of cases \\
\hline Mucosal pathology & 1,851 & 27.8 \\
\hline Tooth pathology & 1,661 & 24.9 \\
\hline Odontogenic cysts and hamartomas & 1,027 & 15.4 \\
\hline Gingival and periodontal pathology & 833 & 12.5 \\
\hline Miscellaneous pathology & 603 & 9.0 \\
\hline Benign tumours & 320 & 4.8 \\
\hline Salivary gland pathology & 261 & 3.9 \\
\hline Bone pathology & 55 & 0.8 \\
\hline Normal tissue & 46 & 0.7 \\
\hline Malignant tumours & 9 & 0.1 \\
\hline Total & $\mathbf{6 , 6 6 6}$ & $\mathbf{1 0 0 . 0}$ \\
\hline
\end{tabular}

\begin{tabular}{|c|c|c|c|}
\hline $\begin{array}{l}\text { Diagnosis } \\
\text { cases }\end{array}$ & No. cases & $\%$ of group & $\%$ total \\
\hline $\begin{array}{l}\text { Mucosal pathology } \\
\text { Fibrous hyperplasia } \\
\text { Hyperkeratosis } \\
\text { Lichenoid drug eruption } \\
\text { Non-specific ulceration } \\
\text { Mucosal inflammation }\end{array}$ & $\begin{array}{l}1,393 \\
183 \\
69 \\
36 \\
28\end{array}$ & $\begin{array}{l}75.3 \\
9.9 \\
3.7 \\
1.9 \\
1.5\end{array}$ & $\begin{array}{l}20.9 \\
2.7 \\
1.0 \\
0.5 \\
0.4\end{array}$ \\
\hline $\begin{array}{l}\text { Tooth pathology } \\
\text { Chronic periapical granuloma } \\
\text { External resorption (tooth) } \\
\text { Dental follicle-normal } \\
\text { Pulp necrosis } \\
\text { Dental follicle-hyperplastic/inflamed }\end{array}$ & $\begin{array}{l}1,334 \\
58 \\
38 \\
38 \\
36\end{array}$ & $\begin{array}{l}80.3 \\
3.5 \\
2.3 \\
2.3 \\
2.2\end{array}$ & $\begin{array}{l}20.0 \\
0.9 \\
0.6 \\
0.6 \\
0.5\end{array}$ \\
\hline $\begin{array}{l}\text { Odontogenic cysts and tumours } \\
\text { Radicular cyst } \\
\text { Paradental cyst } \\
\text { Dentigerous cyst } \\
\text { Residual cyst } \\
\text { Odontomes }\end{array}$ & $\begin{array}{l}822 \\
67 \\
42 \\
38 \\
23\end{array}$ & $\begin{array}{l}80.0 \\
6.5 \\
4.1 \\
3.7 \\
2.2\end{array}$ & $\begin{array}{l}12.3 \\
1.0 \\
0.6 \\
0.6 \\
0.3\end{array}$ \\
\hline $\begin{array}{l}\text { Gingival and periodontal pathology } \\
\text { Fibrous epulis } \\
\text { Pyogenic granuloma } \\
\text { Chronic gingivitis } \\
\text { Periodontitis } \\
\text { Peripheral giant cell granuloma }\end{array}$ & $\begin{array}{l}383 \\
196 \\
122 \\
56 \\
35\end{array}$ & $\begin{array}{l}46.0 \\
23.5 \\
14.7 \\
6.7 \\
4.2\end{array}$ & $\begin{array}{l}5.8 \\
2.9 \\
1.8 \\
0.8 \\
0.5\end{array}$ \\
\hline $\begin{array}{l}\text { Miscellaneous pathology } \\
\text { Non-diagnostic } \\
\text { Scar tissue } \\
\text { Granulation tissue } \\
\text { Sinus } \\
\text { Haemangioma-capillary }\end{array}$ & $\begin{array}{l}140 \\
124 \\
94 \\
49 \\
25\end{array}$ & $\begin{array}{l}23.2 \\
20.6 \\
15.6 \\
8.1 \\
4.1\end{array}$ & $\begin{array}{l}2.1 \\
1.9 \\
1.4 \\
0.7 \\
0.4\end{array}$ \\
\hline $\begin{array}{l}\text { Salivary gland pathology } \\
\text { Mucous extravasation cyst } \\
\text { Mucous retention cyst } \\
\text { Chronic sialoadenitis } \\
\text { Sialolithiasis } \\
\text { Sjögren's syndrome }\end{array}$ & $\begin{array}{l}205 \\
24 \\
19 \\
10 \\
2\end{array}$ & $\begin{array}{l}78.2 \\
9.2 \\
7.3 \\
3.8 \\
0.8\end{array}$ & $\begin{array}{l}3.1 \\
0.4 \\
0.3 \\
0.2 \\
<0.1\end{array}$ \\
\hline $\begin{array}{l}\text { Bone pathology } \\
\text { Sequestrum } \\
\text { Exostosis } \\
\text { Osteitis } \\
\text { Periostitis } \\
\text { Central giant cell granuloma }\end{array}$ & $\begin{array}{l}19 \\
15 \\
6 \\
5 \\
2\end{array}$ & $\begin{array}{l}33.9 \\
26.8 \\
10.7 \\
8.9 \\
3.6\end{array}$ & $\begin{array}{l}0.3 \\
0.2 \\
0.1 \\
0.1 \\
<0.1\end{array}$ \\
\hline
\end{tabular}

using an alphanumeric code comprising two letters, which designates the diagnostic category (eg $\mathrm{OC}=$ odontogenic cysts) and three numbers which refer to the specific condition within the diagnostic category (eg dentigerous cyst $=0$ 0C202). There are 15 diagnostic categories which contain codes for 627 diagnoses and, as these codes are entered, a 'look-up' table containing the diagnoses is used to avoid the input of typographical errors. If necessary, the codes can be linked via further 'look-up' tables to other coding systems such as SNOP (Systematised Nomenclature Of Pathology) or SNOMED (Sytematised Nomenclature Of Medicine).
All entries for specimens submitted by GDPs during the 30-year period 1974-2003 inclusive were retrieved and, for the sake of brevity, the diagnoses compiled into 10 main diagnostic groups. Each diagnosis included number of samples, total percent of diagnostic group and percentage of all submitted samples. In addition, for four selected years (1974, 1984, 1994 and 2003), using the criteria adopted by Williams et al., ${ }^{4}$ the most frequent histological diagnoses were recorded.

\section{RESULTS}

During the 30-year period, 53,474 specimens were received. Over the 30 year period, the total number of cases as well as the number of specimens submitted by GDPs has increased. The total number of biopsy specimens received in the laboratory increased from 524 in 1974 to 2,139 in 2003, a four fold increase. During the same period the number of cases received from GDPs increased from $36(10 \%)$ in 1974 to 370 in $2003(17 \%)$. A total of 6,666 (12.5 $\%$ ) specimens were received from 617 different GDPs. During the period, the majority of GDPs (89\%) submitted between 1-20 specimens. Of the 548 submitting 1-20 specimens, 210 (34\%) submitted only a single specimen and $69(11.2 \%)$ sent in two specimens. However, some practitioners submitted specimens on a more regular basis, 33 GDPs each sent between 21-40 specimens and 16 between 41 and 60. A small number contribute many more specimens and some are known to have a special interest in oral surgery or surgical dentistry. Eight such practitioners submitted over 100 specimens, while four submitted over 200.

Table 1 shows the diagnostic categories for all specimens submitted by GDPs over the 30-year period. Mucosal pathology accounted for nearly 28\% of all cases. Excluding normal tissue as well as benign and malignant tumours, Table 2 shows the five most frequent diagnoses for each of the seven remaining diagnostic groups used in this study.

In the mucosal pathology category, reactive fibrous overgrowths (either denture-induced or related to other forms of trauma) accounted for over 75\% of the specimens. Among the remaining mucosal specimens, 'white' lesions (as represented by lichen planus/lichenoid reaction, hyperkeratosis (no dysplasia), chronic hyperplastic candidosis and epithelial dysplasia) accounted for nearly $16 \%$ of mucosal lesions and $4 \%$ of all submitted specimens.

Among the diagnostic groupings included under the category of tooth pathology, periapical pathology (excluding radicular and residual cysts) comprised 80\%. Of interest, out of a total of 116 cases submitted as dentigerous cysts, only 42 were diagnosed as such. The remaining 74 were diagnosed as either normal or inflamed dental follicles.

Within the odontogenic cysts and hamartoma category, radicular or residual cysts dominated and accounted for approximately $84 \%$ of cases. Localised swellings of the gum (epulides), represented mainly by the fibrous epulis and its immature precursor the pyogenic granuloma/pregnancy epulis, comprised nearly 70\% of the gingival and periodontal pathology category. To facilitate organisation of the data, the miscellaneous group comprised a broad mixture of diagnoses, which could not easily be placed into any other diagnostic category. These included lesions such as nonodontogenic cysts, infections and vascular anomalies. One hundred and forty (23\%) of these cases were classified as non diagnostic, due to insufficient tissue being provided so an adequate diagnosis could be made.

Among the relatively small number of salivary gland specimens $(<4 \%$ of the total), mucoceles accounted for the great majority (87\%). Salivary gland tumours are included under benign and malignant tumours (Tables 3 and 4 respectively). Having included periapical pathology and odontogenic cysts and tumours under other categories, the remaining examples of bone pathology comprised the smallest diagnostic group $(<1 \%$ of all GDP specimens) 
but included some notable diagnoses, such as central giant cell granuloma and fibrous dysplasia.

Overall, 320 benign (Table 3) and nine malignant neoplasms (Table 4) were found; of the benign tumours, localised papilliferous lesions, either squamous papillomas or verrucae vulgaris (viral warts), represented the most common diagnosis (80\%). Of the less frequent benign tumours neurofibroma and lipoma were the most common. However, other important diagnoses included a small number of rare benign neoplasms such as cementoblastoma, myoepithelioma and odontogenic myxoma. A total of nine salivary tumours were diagnosed, eight of which were benign adenomas and one mucoepidermoid carcinoma. Nine malignant tumours were diagnosed, the most common of which were squamous cell carcinoma (three cases) and surprisingly non Hodgkin's lymphoma (three cases).

In order to make comparisons between our data and those of Williams et al., ${ }^{4}$ the results from four selected years (1974, 1984, 1994 and 2003) have been compiled (Table 5). There was a marked increase in the number of diagnostic categories between 1974 and 1984 , but after this date there has been only a slight increase in the variety of histological diagnoses. In 1974, 1984 and 1994, a diagnosis of fibrous hyperplasia (including nodules or denture related hyperplasia) was the most frequent, whereas in 2003, periapical granuloma was the most frequent. However, of the first three most frequent diagnoses in each selected year, the percentage of cases diagnosed as periapical pathology increased by approximately 10\% per decade. In 1974 periapical pathology accounted for 16.7\% of GDP samples while in 2003 this increased to 43.8\%.

Other significant diagnoses (ie requiring subsequent treatment or monitoring) included lichen planus or lichenoid reaction (69 cases), epithelial dysplasia (20 cases), mucous membrane pemphigoid (four cases), chronic hyperplastic candidosis (22 cases), odontogenic keratocysts (seven cases), Sjögren's syndrome (two cases) and central giant cell granuloma (two cases).

\section{DISCUSSION}

It is well within the scope of specialist practitioners in surgical dentistry and GDPs to carry out small incisional or excisional biopsies rather than refer them. In view of the fact that only nine of the submitted specimens were from malignant lesions, it would appear that the majority of clinically suspicious lesions are referred to hospital. This is similar to the findings in the Birmingham study. ${ }^{4}$ We would agree with them that it is better to leave biopsy of lesions suspected of being malignant to the oral and maxillofacial surgeon who will be undertaking the definitive treatment.

Two important 'diagnostic' categories where a diagnosis may not be possible are (1) unfixed specimens, where usually the specimens had been placed in water or normal saline solution rather than 10\% buffered formalin (if the latter is not available, alcohol may even be used, in the form of gin or other such clear alcoholic beverages) and (2) non-diagnostic category in which most often, submitted specimens comprise insufficient material on which to make a diagnosis or where a mucosal biopsy was too shallow to show the underlying connective tissue. Approximately $2.1 \%$ of all GDP specimens were classified as non diagnostic, compared with $1.7 \%$ of all other practitioners. This is reassuring and suggests that GDPs are as capable of obtaining biopsies as their hospital colleagues, hence supporting the view that all dental practitioners possess sufficient skill to remove and submit tissue to a pathologist. ${ }^{7}$ Only 17 cases were classified as artefacts which precluded diagnosis, compared with four cases from hospital staff. An artefact refers to an alteration to the surgical specimen, as a result of extraneous factors. ${ }^{7}$ This can occur at any time during the procedure including surgical, fixation and preparation artefacts. Seoane et $a .^{7}$ reported that over $64 \%$ of specimens submitted by GDPs

\begin{tabular}{|c|c|c|c|}
\hline $\begin{array}{l}\text { Diagnosis } \\
\text { cases }\end{array}$ & No. cases & $\%$ of group & $\%$ total \\
\hline Squamous papilloma & 256 & 80.0 & 3.8 \\
\hline Neurofibroma & 29 & 9.1 & 0.4 \\
\hline Lipoma & 7 & 2.2 & 0.1 \\
\hline Fibrolipoma & 5 & 1.6 & 0.1 \\
\hline Pleomorphic salivary adenoma & 5 & 1.6 & 0.1 \\
\hline Neurilemmoma & 4 & 1.3 & 0.1 \\
\hline Giant cell fibroma & 2 & 0.6 & $<0.1$ \\
\hline Lymphangioma & 2 & 0.6 & $<0.1$ \\
\hline Monomorphic adenoma & 2 & 0.6 & $<0.1$ \\
\hline Traumatic neuroma & 2 & 0.6 & $<0.1$ \\
\hline Angiomyoma & 1 & 0.3 & $<0.1$ \\
\hline Cementoblastoma & 1 & 0.3 & $<0.1$ \\
\hline Myoepithelioma & 1 & 0.3 & $<0.1$ \\
\hline Odontogenic myxoma & 1 & 0.3 & $<0.1$ \\
\hline Ossifying fibroma & 1 & 0.3 & $<0.1$ \\
\hline Sialoadenoma papilliferum & 1 & 0.3 & $<0.1$ \\
\hline Total & 320 & 100 & 4.8 \\
\hline
\end{tabular}

\begin{tabular}{llll}
\hline Table 4 Malignant tumours & No. cases & \% of group & $\begin{array}{l}\% \text { total } \\
\text { cases }\end{array}$ \\
\hline Diagnosis & 3 & 33.3 & $<0.1$ \\
\hline Non-hodgkin's lymphoma & 3 & 33.3 & $<0.1$ \\
\hline Squamous cell carcinoma & 1 & 11.1 & $<0.1$ \\
\hline Chondrosarcoma & 1 & 11.1 & $<0.1$ \\
\hline Metastatic carcinoma & 1 & 11.1 & $<0.1$ \\
\hline Mucoepidermoid carcinoma & $\mathbf{9}$ & $\mathbf{1 0 0}$ & $\mathbf{0 . 1}$ \\
\hline Total & & &
\end{tabular}

contained features such as crush artefacts, however they did not specify the number which precluded diagnosis.

In our study, mucosal pathology was the most common diagnostic category followed by tooth related pathology. The most frequent diagnosis was that of fibrous hyperplasia (in the form of a fibroepithelial polyp) followed by chronic periapical pathology and radicular cysts. This is similar to the findings of Williams et $a .^{4}$ and Weir et al., ${ }^{6}$ where fibroepithelial polyps were the most common lesions submitted. However, in the latter study, periapical granuloma and radicular cyst were the second and fifth most frequently diagnosed lesions, while mucoceles and periodontitis were third and fourth respectively. Although radicular cysts were the most frequently diagnosed odontogenic cyst, the potential importance of establishing a diagnosis for patients presenting with important lesions such as odontogenic myxoma or an odontogenic keratocyst should not be underestimated.

Considering the increased awareness of practitioners to the risk of premalignant change in white lesions, it is perhaps surprising, in our study, that there were few such lesions biopsied. Hyperkeratosis comprised nearly $10 \%$ (183) of mucosal diagnoses, while only $1.1 \%$ (20) of the mucosal lesions were dysplastic. Again, this is slightly different from the findings of Williams et al.,${ }^{4}$ who found a gradual increase, over 20 years, in the number of biopsies of white patches (6.2\% in 1994). This compares with our findings of around 2.0\% in 1994. The explanation may simply be that in this region more practitioners refer patients for a biopsy rather than do it themselves. However, we cannot exclude the possibility that such lesions are more common in the West Midlands region. In future, it is possible that specialists in surgical dentistry may take a different approach. The frequency of squamous cell carcinoma is likely to be grossly underestimated due to the immediate referral of suspicious lesions to local departments of oral and maxillofacial surgery. An unusual 


\begin{tabular}{|c|c|c|c|}
\hline $\begin{array}{l}1974 \\
36 \text { specimens }\end{array}$ & $\begin{array}{l}1984 \\
173 \text { specimens }\end{array}$ & $\begin{array}{l}1994 \\
286 \text { specimens }\end{array}$ & $\begin{array}{l}2003 \\
370 \text { specimens }\end{array}$ \\
\hline \multirow[t]{12}{*}{$\begin{array}{l}\text { Fibrous } \\
\text { hyperplasia } \\
(19.4 \%)(n=7)\end{array}$} & $\begin{array}{l}\text { Fibrous } \\
\text { hyperplasia } \\
(n=48)(27.7 \%)\end{array}$ & $\begin{array}{l}\text { Fibrous } \\
\text { hyperplasia } \\
(n=70)(24.5 \%)\end{array}$ & $\begin{array}{l}\text { Periapical } \\
\text { granuloma } \\
(n=108)(29.2 \%)\end{array}$ \\
\hline & $\begin{array}{l}\text { Radicular } \\
\text { cyst } \\
(n=22)(12.7 \%)\end{array}$ & $\begin{array}{l}\text { Periapical } \\
\text { granuloma } \\
(n=59)(20.6 \%)\end{array}$ & $\begin{array}{l}\text { Fibrous } \\
\text { hyperplasia } \\
(n=80)(21.6 \%)\end{array}$ \\
\hline & $\begin{array}{l}\text { Periapical } \\
\text { granuloma } \\
(n=21)(12.1 \%)\end{array}$ & $\begin{array}{l}\text { Radicular } \\
\text { cyst } \\
(n=41)(14.3 \%)\end{array}$ & $\begin{array}{l}\text { Radicular } \\
\text { cyst } \\
(n=54)(14.6 \%)\end{array}$ \\
\hline & $\begin{array}{l}\text { Mucocele } \\
(n=9)(5.2 \%)\end{array}$ & $\begin{array}{l}\text { Fibrous epulis } \\
(n=21)(7.3 \%)\end{array}$ & $\begin{array}{l}\text { Fibrous epulis } \\
(n=16)(4.3 \%)\end{array}$ \\
\hline & $\begin{array}{l}\text { Pyogenic } \\
\text { granuloma } \\
(n=9)(5.2 \%)\end{array}$ & $\begin{array}{l}\text { Mucocele } \\
(n=11)(3.8 \%)\end{array}$ & $\begin{array}{l}\text { Mucocelle } \\
(n=14)(3.8 \%)\end{array}$ \\
\hline & $\begin{array}{l}\text { Fibrous epulis } \\
(n=7)(4.0 \%)\end{array}$ & $\begin{array}{l}\text { Squamous } \\
\text { papilloma } \\
(n=10)(3.5 \%)\end{array}$ & $\begin{array}{l}\text { Hyperkeratosis } \\
(n=9)(2.4 \%)\end{array}$ \\
\hline & $\begin{array}{l}\text { Non diagnostic } \\
(n=7)(4.0 \%)\end{array}$ & $\begin{array}{l}\text { Pyogenic } \\
\text { granuloma } \\
(n=7)(2.4 \%)\end{array}$ & $\begin{array}{l}\text { Scar tissue } \\
(n=8)(2.2 \%)\end{array}$ \\
\hline & $\begin{array}{l}\text { Hyperkeratosis } \\
(n=6)(3.5 \%)\end{array}$ & $\begin{array}{l}\text { Hyperkeratosis } \\
(n=5)(1.7 \%)\end{array}$ & $\begin{array}{l}\text { Granulation tissue } \\
(n=6)(1.6 \%)\end{array}$ \\
\hline & & & $\begin{array}{l}\text { Lichen planus } \\
(n=6)(1.6 \%)\end{array}$ \\
\hline & & & $\begin{array}{l}\text { Non diagnostic } \\
(n=6)(1.6 \%)\end{array}$ \\
\hline & & & $\begin{array}{l}\text { Pyogenic } \\
\text { granuloma } \\
(n=6)(1.6 \%)\end{array}$ \\
\hline & & & $\begin{array}{l}\text { Squamous } \\
\text { papilloma } \\
(n=6)(1.6 \%)\end{array}$ \\
\hline $\begin{array}{l}\text { Total } n=7 \\
(19.4 \%)\end{array}$ & $\begin{array}{l}\text { Total } n=129 \\
(74.6 \%)\end{array}$ & $\begin{array}{l}\text { Total } n=224 \\
(78.3 \%)\end{array}$ & $\begin{array}{l}\text { Total } n=319 \\
(86.2 \%)\end{array}$ \\
\hline
\end{tabular}

*Non diagnostic: specimens too small or inadequate in some way or another for accurate reporting

finding was the single case of a deposit of metastatic breast tumour in a male patient previously reported by one of $\mathrm{us}^{8}$ and a case of non Hodgkin's lymphoma which were submitted as periapical granulomas. The discovery of unsuspected pathology in specimens reinforces the importance and need to submit all surgically removed tissue for histological diagnosis.

It is clear that the small number of GDPs who regularly submit specimens to us diagnose much significant pathology. In 1984, about 11\% (117) of our specimens were provided by general dental practitioners. Until 1990, this figure had been relatively stable, but from 1991 there has been a gradual increase and, in 2003, the figure was just over 17\% (370). This may reflect the increased encouragement we have given to recent graduates to send in their material. Also, changes in undergraduate teaching in oral and maxillofacial surgery as well as specific postgraduate courses in oral surgery for general dental practitioners may have helped to bring about this increase. As has happened in Sheffield, it is likely that as the number of specialists or dentists with a special interest in surgical dentistry increases, there will be a further increase in the number of specimens submitted by these groups of practitioners. However, there are many practitioners who do not submit pathological material for diagnosis. For example, allowing for the few dentists outside the SY/EM region who send us specimens, we estimate that about $85 \%$ of the 1,800 dentists in the region do not send any material to us. It is difficult to understand why more practitioners apparently do not submit specimens for histopathological examination. It may be important for medico-legal reasons that all tissue removed from patients should be submitted for histological examination. Of course, it is not known whether they send material to other laboratories either of general or oral pathology.

GDPs have suggested the current NHS biopsy fee requires revision, while hospital surgeons have suggested this fee is too low and hence discourages GDPs from undertaking biopsy samples. ${ }^{1}$ In the new UK NHS contract for primary care dental practitioners, there will be no fee provided for submitting a specimen as such work is already built into the contract. However, this should not be seen as a disincentive to GDPs since from a clinical governance and patient care perspective, obtaining a histopathological report on surgically removed tissue is essential. Furthermore, in the past, GDPs were not charged for the pathology service $;^{9}$ with the new contract, there is no reason why primary care trusts should not be charged.

\section{CONCLUSION}

It is clear that GDPs have provided an increased number of biopsy specimens over the last three decades and their use of a diagnostic histopathology service should be encouraged. Although the vast majority of such lesions will be innocuous, occasionally important diagnoses are made. Specimens submitted by specialist and general dental practitioners provide a valuable resource for teaching and research in departments such as ours, as well as useful clinical audit and research material for practitioners. In addition specimens sent through the mail must, of course, comply with postal regulations and oral pathology departments will provide advice on the sending of such specimens, together with specimen bottles, fixative and request forms.

The senior author (CDF) who devised the database wishes to acknowledge the diagnostic input to the database of his two colleagues Professor C. J. Smith (now retired) and Dr Geoffrey Craig without whom the database would not be available to use. We also wish to thank the various technicians and secretaries who, over the years, have inputted data and supported the day-to-day work of the surgical diagnostic service.

1. Diamanti N, Duxbury A J, Ariyaratnam S, Macfarlane T V. Attitudes to biopsy procedures in general dental practice. Br Dent J. 2002; 192: 588-592.

2. Odell E W, Farthing P M, High A et al. British Society for Oral and Maxillofacia Pathology, UK: minimum curriculum in oral pathology. Eur J Dent Ed 2004; 8: 177-184.

3. Thomas D, Walker R, Smith A, Shepherd J. The provision of oral surgery services in England and Wales 1984-1991. BrDent J 1994; 176: 215-219.

4. Williams H K Hey A A, Browne R M. The use by general dental practitioners of an ora pathology diagnostic service over a 20-year period: the Birmingham experience. $B$ Dent J 1997; 182: 424-429

5. Levy B A, Lunin M. Which dentists do biopsies? JMd State Dent Assoc 1981:24: 24-25.

6. Weir J D, Davenport, W D, Skinner, R L. A diagnostic and epidemiologic survey of 15,783 oral lesions. J Am Dent Ass 1987; 115: 439-442.

7. Seoane J, Varela-Centelles PI, Ramirez J R et al. Artefacts in oral incisional biopsies in general dental practice: a pathology audit. Oral Dis 2004; 10: 113-117.

8. Franklin C D, Kunkler I H. Carcinoma of the male breast metastatic to the mandible Clin Oncol 1992: 4: 62-63.

9. Odell E W, Morgan P R. Letters: Practitioner biopsy services. Br Dent J 2002; 193: 182. 